I 緒言

Yakel1) が1955年に種々のペロブスカイト構造の酸化 物に関する論文を Acta. Cryst. に発表したが，その中で 彼は $\mathrm{SrFeO}_{3}$ に执いて $\mathrm{Fe}$ 中にはかなり多くの $\mathrm{Fe}^{4+}$ が 含まれていることを指摘している，乙れが著者の興味を そそったのが本研究のキッカケである.アルカり土類フ エライトおよびコバルタイトは㜔成，熟姏理の条件如何 に上って結晶構造，磁性が大いに変わるが，これは主と して $\mathrm{Fe}^{4+} ゃ \mathrm{Co}^{4+}$ の存在割合が变わることによるすの である. 約15年前に㵔者の一人 2 はこのととに気づき 4 価イオン量亡磁性, 霞気伝導度などの関係老調べたが, 浸近さらに詳しい研究を行なったのでメスバウァ一效 果や中性子回折による磁気構造のデータも併せててこに 紹介する。

\section{II 結晶構造亡超交換相互作用}

（1）ペロブスカイト型構造

理想的なペロブスカイト型楧造の単位胞は, 図 1 亿示 すように体心に大きいAイオン（今の場合アルカリ土類 金属イオン)，体䧉に小さいBイオン（今の場合鉄族イ オン) がある立方体で，各稜の中点に酸素イオンがある. $\mathrm{SrFeO}_{3}{ }^{3)}, \mathrm{SrCoO}_{3}$ の高温相 ${ }^{4)}, \mathrm{CaFeO}_{3}{ }^{5)}$ がこれ亿属す

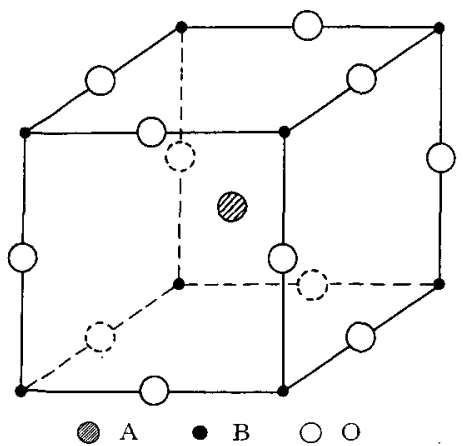

図1ペロブスカイト酸化物の磁気構造
$\mathrm{A}$ ：大きい陽イオン $\mathrm{Ca}^{2+}, \mathrm{Sr}^{2+}$
$\mathrm{B}$ : 小さい陽イオン $\mathrm{Fe}^{3+}, \mathrm{Fe}^{4+} ; \mathrm{Co}^{3+}, \mathrm{Co}^{4+}$
$\mathrm{O}$ : 酸素イオン $\mathrm{O}^{2-}$

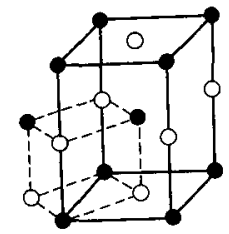

(a)

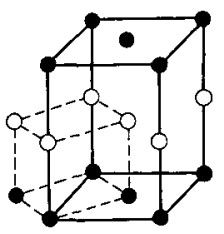

(b)
上向きスピン $○$ 下向きスピン

図 2 ペロブスカイト酸化物に就ける2つの磁気構造 （点線はペロブスカイトの基本格子）
(a) G 型
(b) A 型

る. 磁性に重要な超交換相互作用は最近接のB イオン同 志が $\mathrm{O}^{2-}$ を介する $180^{\circ}$ 相互作用である6). 従来知られ ている同型の酸化物では磁気構造は $\mathrm{G}$ 型（図 $2(\mathrm{a})$ ，例 $\mathrm{LaFeO}_{3}, \mathrm{LaCrO}_{3}$ など）またはA型（図 $2(\mathrm{~b}) ，$ 例えば $\mathrm{LaMnO}_{3}$ ) であるが，後述するように $\mathrm{SrFeO}_{3}$ はそのい ずれであない.

（2）ブラウンミレライト型構造

最初 Bertaut?) らによって $\mathrm{Ca}_{2} \mathrm{Fe}_{2} \mathrm{O}_{5}$ がこの榗造をも

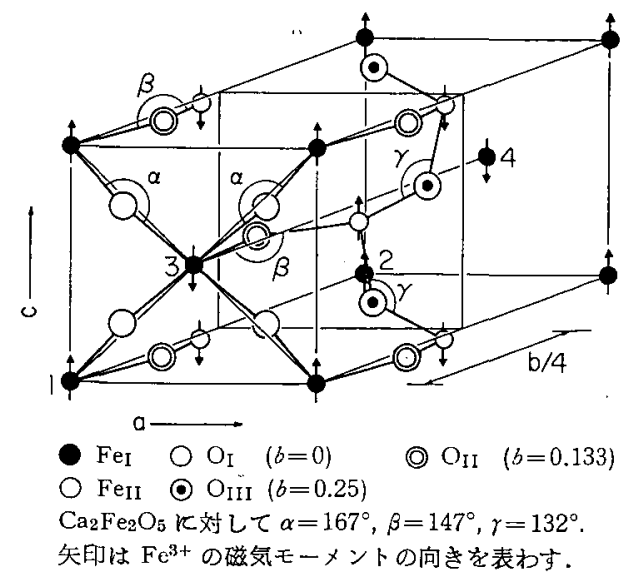

図3ブラウンミレライト型結晶構造と磁気構造

* 昭和 47 年 5 月受崱記念講演会にて講演，昭和 47 年12月 8 日 受理

** 東北大学金属材料研桇所，仙台市片平2-1-1

$\dagger$ 現在広島大学教養部, 広島市東干田町1-1-89 
つことが示されてから注目されるようになった，それは 空間群 $P c m n-D_{2}{ }^{16}$ 亿属し, 斜方晶である. $\mathrm{Ca}_{2} \mathrm{Fe}_{2} \mathrm{O}_{5}$ の格子常数は $a=5.64, b=14.68, c=5.39 \AA$ である. この 構造拉よび磁気構造を四 3 亿示す.

$\mathrm{Fe}$ には 2 種粸の結晶学的位置があり，図には $\mathrm{Fe}_{\mathrm{I}}$ と $\mathrm{Fe}_{\mathrm{II}}$ で示してあるが， $b$ 軸に沿うて交互に現れる．Fe $\mathrm{e}_{\mathrm{I}}$ は八面体位置で 6 個の酸素によって园まれ， $\mathrm{Fe}_{\mathrm{II}}$ は四面 体位置で 4 個の酸素によって囲まれる，ての構造は酸素 の欠如した，歪んだペロブスカイト構造とみなすととが できる. 単位胞はペロブスカイトの基本胞が 4 個 $b$ 軸方 向に積重なったようなあのである．したがってての構造 をすつ酸化物 $\mathrm{Ca}_{2} \mathrm{Fe}_{2} \mathrm{O}_{5}, \mathrm{Sr}_{2} \mathrm{Fe}_{2} \mathrm{O}_{5}, \mathrm{Sr}_{2} \mathrm{Co}_{2} \mathrm{O}_{5}$ はすべて G 型である之考えられる。 G型は図から放るように相 隣る $\mathrm{B}^{3+}$ イオンが反対问きの磁気モーメントをもって いる. したがって $\mathrm{Fe}_{\mathrm{I}}$ と $\mathrm{Fe}_{\mathrm{II}}$ は相互に反強磁性的江結 合しているばかりでなく，それ自身むそれぞれ反強磁性 的红結合している.

（3） $\mathrm{BaNiO}_{3}$ 型構造

$\mathrm{SrCoO}_{3}$ には低温相と高温相の両相があることが本研 究4) から知られたが，そのうち低温相は $\mathrm{BaNiO}_{3}$ 型の構 造をもっている，てれは六方晶であるが，図4 亿高温相 のペロブスカイト型構造のあのとの比較を示してある. ペロブスカイト型の方はその (111) 朝を上下方向ととっ

(A)

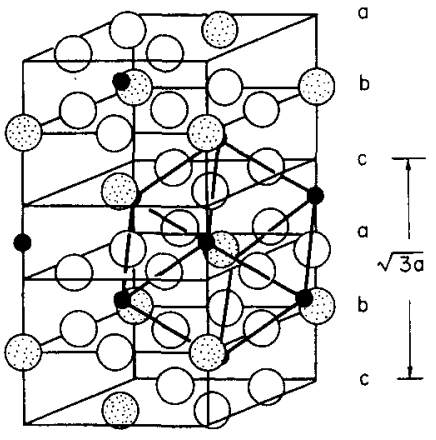

(B)

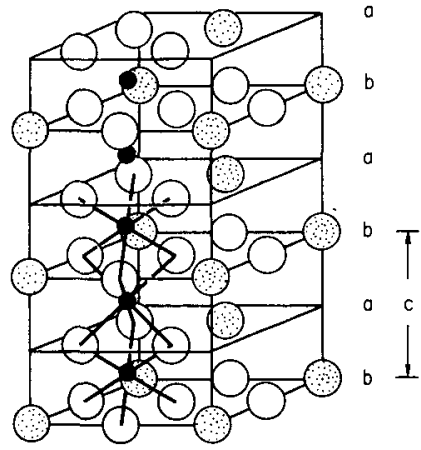

図 4 (A) ペロブスカイト型棈造と (B) $\mathrm{BaNiO}_{3}$ 型構造の比較 太線は Co-O-Co の超交換相互作用の途筋

てあり，(111) 面の積層は $a b c$ 型である. $\mathrm{BaNiO}_{3}$ 型で は $c$ 朝を上下方向にとってあり， $c$ 面の積層は $a b$ 型で ある. 両構造の重要なちがいはペロブスカイト型構造で は Co-O-Co の結合角は前述のように $180^{\circ}$ であるが， $\mathrm{BaNiO}_{3}$ 型構造ではそれは約 $90^{\circ}$ に近いとよである.さ らに後者ではこの結合に与る Co 原子は $c$ 軸方向に並ん でいるが，c面内での Co 原子同志は 2 つの酸素を介さ なりれば結合しない，したがってての構造では磁性は弱 いはずである。

\section{III $\mathrm{Ca}_{2} \mathrm{Fe}_{2} \mathrm{O}_{5}$ の磁性}

$\mathrm{CaCO}_{3}$ ¿ $\mathrm{Fe}_{2} \mathrm{O}_{3}$ の所定モル此湿合物を $1200^{\circ} \mathrm{C} て ゙ す$ 気中 $3 \mathrm{hr}$ 烧成し， $1150^{\circ} \mathrm{C}$ で $3 \mathrm{hr}$ 焼鈍した粉末試料は確 がにブラウンミレライト型の結晶構造をもつてとがX線 回折により知られた．乙の試料の磁化温度曲線は図 5 に 示すように $T_{c}=720^{\circ} \mathrm{K}$ の弱強磁性であることを示す.

一方メスバウァ効果のデータをとると， $579^{\circ} \mathrm{K}$ の高温

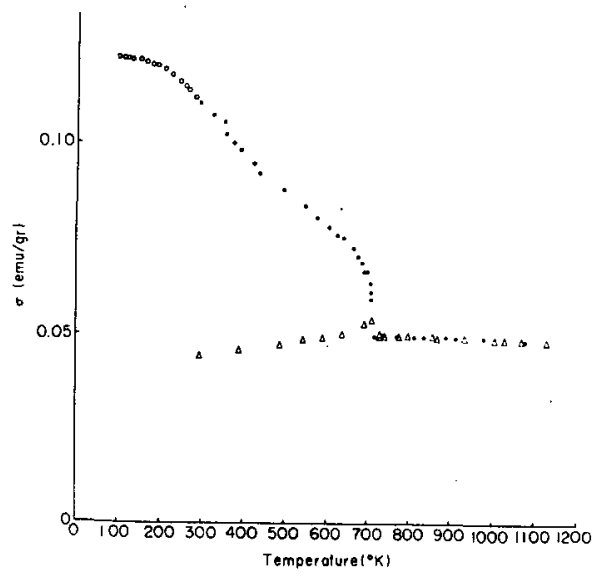

図 $5 \mathrm{Ca}_{2} \mathrm{Fe}_{2} \mathrm{O}_{5}$ の磁化温度曲線（磁場 3950 Oe） $\triangle$ 加熱時測定 - 冷却時測定

で屯強い内部磁場 $H_{i}$ が存在 $\mathrm{L}, \mathrm{Fe}_{1}$ 位置 の $H_{i}=390 k \mathrm{Oe}, \mathrm{Fe}_{\mathrm{II}}$ 位置の $H_{i}=296 k \mathrm{Oe}$ て ある. 全磁化が小さいのに内部磁場がこの ように大さいととは，この物犋が寄生強磁 性をあった反強磁性であることを物語って いる. $\mathrm{Fe}_{\mathrm{II}}$ の内部磁場が $\mathrm{Fe}_{\mathfrak{I}}$ の内部磁場よ り小さいのは洪有結合性の影響が四的体位 置で強いことを示す，四重極分離 $\Delta E$ お び 310 stainless steel に站する isomer shift $\delta$ は八面体位置ではそれぞれ $-0.29 \mathrm{~mm} / \mathrm{sec}$

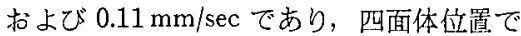
それぞれ $0.32 \mathrm{~mm} / \mathrm{sec}$ および $-0.05 \mathrm{~mm} /$ sec である。

反強嗞性の磁気構造を調べるため，原研 JRR-3 亿設置されたTOG-ND 装置で中性 子回折契験を行なった，液空温度，入射中性子波長 $\lambda=$ $1.02_{8} \AA$ の場合のデータを図 6 に示す.

この回折像に抢いて，指数は空間群P c mn に関してつ けてある.ことで顕著な磁気散乱線は (120)と(021)の 重畳したあのである. この回折像は（1）chemical unit cell で指数付けができる.（2）弱い強磁性しか示さない， (3) (020)，(121）の磁気散乱線が钼测されない，(4) (120)，(021) の磁気散乱線が強い，なごの理由から，図 2 に示した G 型反強磁性構造をもつととが知られる. $(120)+(021)$ の線強度の温度変化を逐うことにより，

「粉体および粉末冶金」第19\%第 8 号 


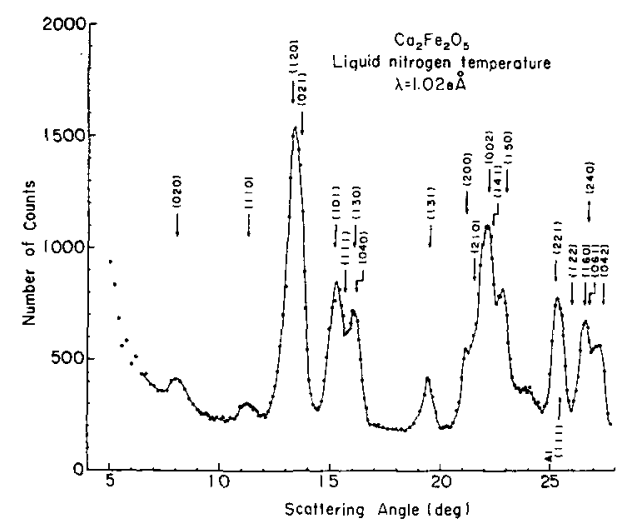

図6 $\mathrm{Ca}_{2} \mathrm{Fe}_{2} \mathrm{O}_{5}$ の中性子回折像 (液窒温度 $(\lambda=1,028 \AA)$

反強磁性のネール温度 $T_{\mathrm{N}}$ が寄生強磁性のキューリ一温 度 $T_{c}$ 亿等しく，720K であることがわかる，絶対 0 度 で磁化は $\mathrm{Fe}^{3+} 1$ 個当り $4.6 \mu_{\mathrm{B}}$ である.これは $\mathrm{Fe}^{3+}$ ( $\left.d^{5}\right)$ の high spin state に対応する値 $5 \mu_{\mathrm{B}}$ より少し小さ く，其有結合性の影響か現れている。磁気モーメントの 結晶軸儿対する向きを知るに恃，(120）上（021）が分離 される必要があるが，データを丁寧にとると図 7 に示す ように (021) による局が現れ，(120) 線の方が (021) 線 よりも強度の大きいとと（理諭的仙は 3:1）がわかり， 磁気モーメントは $c$ 軸方向を向いているととが加るる. 寄生强磁性出現の原因は Dzyaloshinsky-Moriya 相互作 用によりスピンの方向がし軸からわずか傾いていて，そ

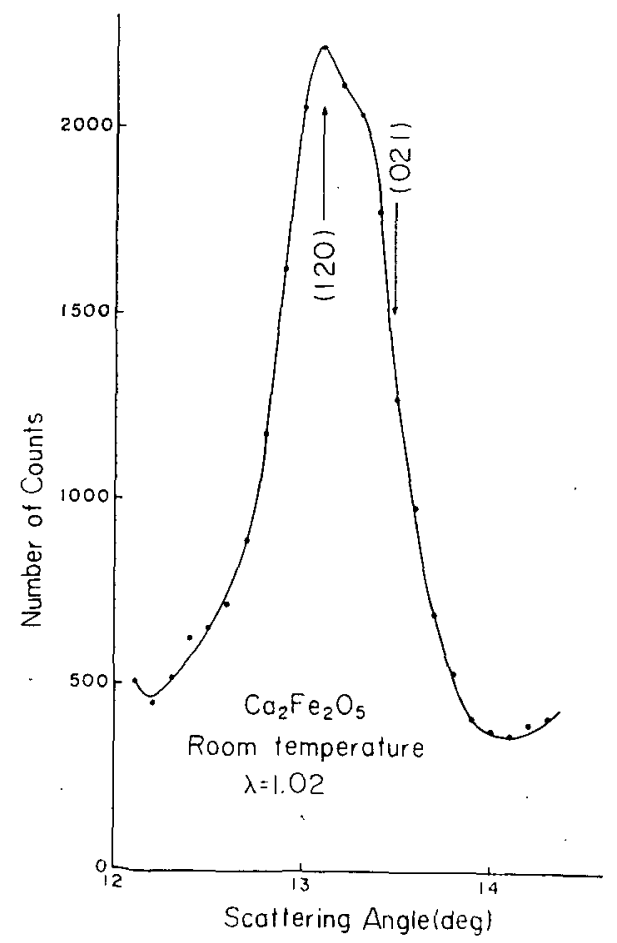

図 $7 \mathrm{Ca}_{2} \mathrm{Fe}_{2} \mathrm{O}_{5}$ の磁気散乱線 $(120)+(021)$ のライン・ プロフィル
の傾いている成分が全体として打消さないととによる。 との强磁性モーメントの生ずる方向は Bartaut の群論の 識諭8)により $a$ 軸方向であるととがわかる.

\section{N $\quad \mathrm{Sr}_{2} \mathrm{Fe}_{2} \mathrm{O}_{5}$.の磁性と結晶構造}

$\mathrm{Sr}_{2} \mathrm{Fe}_{2} \mathrm{O}_{5}$ の逆带磁率-温度曲線は古いデータ2)によ っても新しいデータ9)によっても反強磁性を示す極小が あり，図 8 亿示すように $T_{\mathrm{N}}=720^{\circ} \mathrm{K}$ である. $\mathrm{Ca}_{2} \mathrm{Fe}_{2} \mathrm{O}_{5}$ との重要なちがいは寄生強磁性をむたないととである. Gallagher ${ }^{10)}$ らはこのものはブラウンシレライト棈造を あっと結論した．しかし以下に示すようにてうではな い.メスバウァ一效果の测定結果では室温で八面体位䈯 क) $H_{i}=492 k \mathrm{Oe}, \Delta E=-0.34 \mathrm{~mm} / \mathrm{sec}, \delta=0.44 \mathrm{~mm} / \mathrm{sec}$; 四面体位置の $H_{i}=406 \mathrm{kOe}, \Delta E=0.24 \mathrm{~mm} / \mathrm{sec}, \delta=0.25$ $\mathrm{mm} / \mathrm{sec}$ である、Hi $H_{i}$ の大さはしのものが反強磁性であ るととを確かにしている.

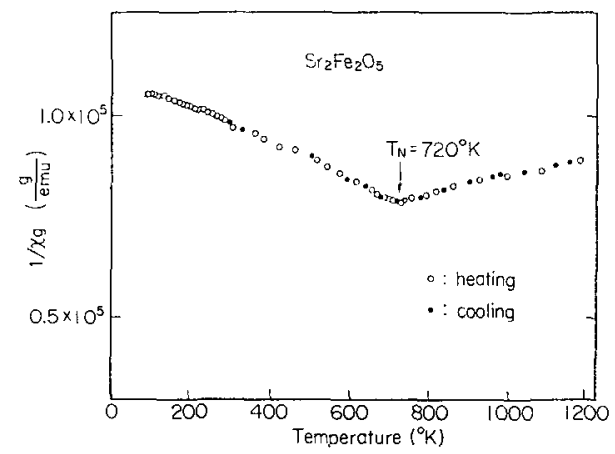

図 $8 \quad \mathrm{Sr}_{2} \mathrm{Fe}_{2} \mathrm{O}_{5}$ の逆带磁率一温度曲線

中性子回折の実験結果 ${ }^{11)}$ 亿上れば，磁気散乱線のあら われ方は $\mathrm{Ca}_{2} \mathrm{Fe}_{2} \mathrm{O}_{5}$ 亡類似しており，(120)+(021) 線 が強い磁気散乱線となっていることにかわりない，ただ (120) と (021) の重なりの程度は $\mathrm{Ca}_{2} \mathrm{Fe}_{2} \mathrm{O}_{5}$ よりも強い ので，耐者を少しであ分離してみようとするには中性子 の波長を長くしなければならなかった. 図 9 はそのよう なデータである。このような結果から,ややはり $\mathrm{Ca}_{2} \mathrm{Fe}_{2} \mathrm{O}_{5}$ 同様 $\mathrm{Fe}^{3+}$ の磁気モーメントは 6 軸方向を向いているは ずである*．ところが，羊しての物質の空間群が $\mathrm{Gal}$. lagher らのいうようにブラウンミレライトのP P cmnであ るならば，Dzyaloshinsky-Moriya 型の相互作用により $\mathrm{Ca}_{2} \mathrm{Fe}_{2} \mathrm{O}_{5}$ 同様寄生強磁性が発生しなければならない. しかし図 8 に示すように等生强磁性は存在しない加ら， その空間群はまちがっているはずである．現在のとてろ 正しい空間群が何であるかは未決定であるが，Icmm か

*この点炕関して我々は東北大学電子ライナックを用いて中 性子回折の実験を行ない，(120）と（021）をさらに上く分 離してこの結論を確固不動のものとした（東北大学核理研 報告 vol. 2 (1969), No. 1, pp. 87〜90 K紹介されている. 詳しく林別任発表の予定)。 


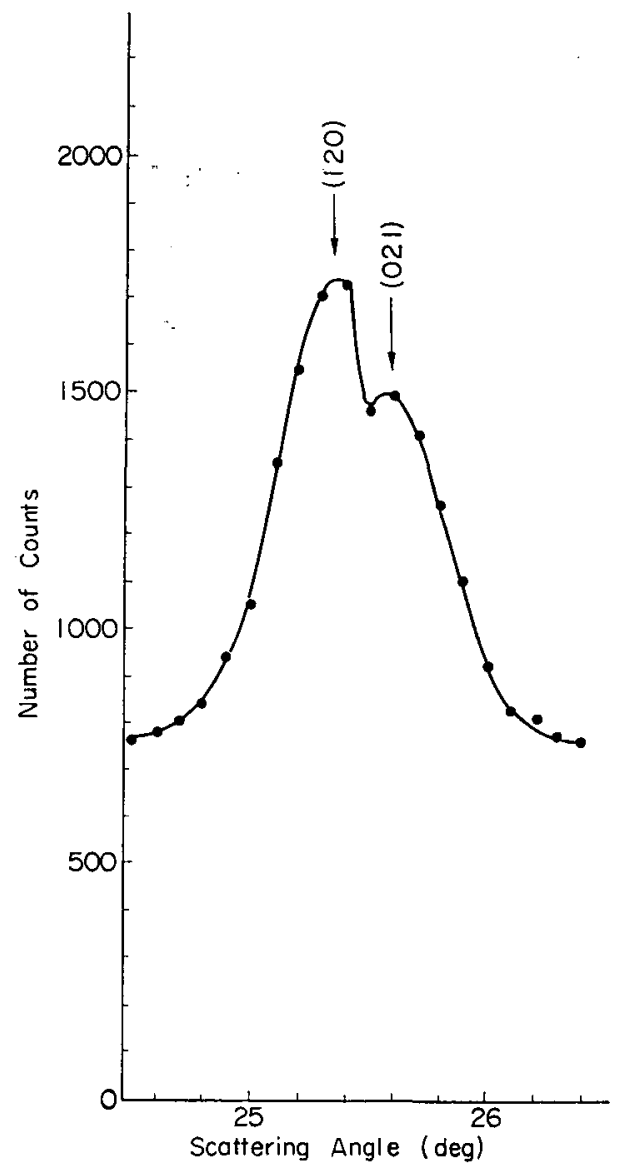

図 $9 \mathrm{Sr}_{2} \mathrm{Fe}_{2} \mathrm{O}_{5}$ の磁気散乱線 $(120)+(021)$ のラインプロ フィル (室温 $\lambda=2.01 \AA$ )

または $l b m 2$ であると思われる*.

$\mathrm{Fe}^{3+}$ の磁気モーメントの值は $4.5 \mu_{\mathrm{B}}$ である. $\mathrm{Ca}_{2} \mathrm{Fe}_{2} \mathrm{O}_{5}$ 同様共有結合性のために $5 \mu_{\mathrm{B}}$ より低い值をとっていると 思われる.

\section{$\mathrm{V} \quad \mathrm{SrFeO}_{3}{ }^{12}$}

$\mathrm{SrFeO}_{3}$ およよび $\mathrm{SrCoO}_{3}$ の高温相試料高酸素珐下でな いと作ることができない．本研究では内径 $18 \mathrm{~mm}$, 外佳 $45 \mathrm{~mm}$, 長さ $300 \mathrm{~mm}$ の NAS-H-40-2 鋼製の外熱型才一 トクレーブを使用した，空気中で予供烧成した試料原料 を入れたオートクレーブに，ボンべからの酸素を液窒温 度に冷却して充填した後, 加熱した.

$\mathrm{SrFeO}_{3}$ の作製には 350 気压の酸素中で $450^{\circ} \mathrm{C}$ から約 1 週間に $250^{\circ} \mathrm{C}$ まで徐冷した. 得られた試料の逆帯磁 泙一温度曲線は図10亿示すように $134^{\circ} \mathrm{K}$ に極小があり， それが反強磁性の $T_{\mathrm{N}}$ に相当する， $T_{\mathrm{N}}$ 以上の帯磁率は キューリー・ワイス則に從わず, $300^{\circ} \mathrm{K}$ 付近の狭い温度 箐围のデータから求めた常磁性キューリー温度は $50^{\circ} \mathrm{K}$ で正である．とのようなデータはすでに MacChesney13)

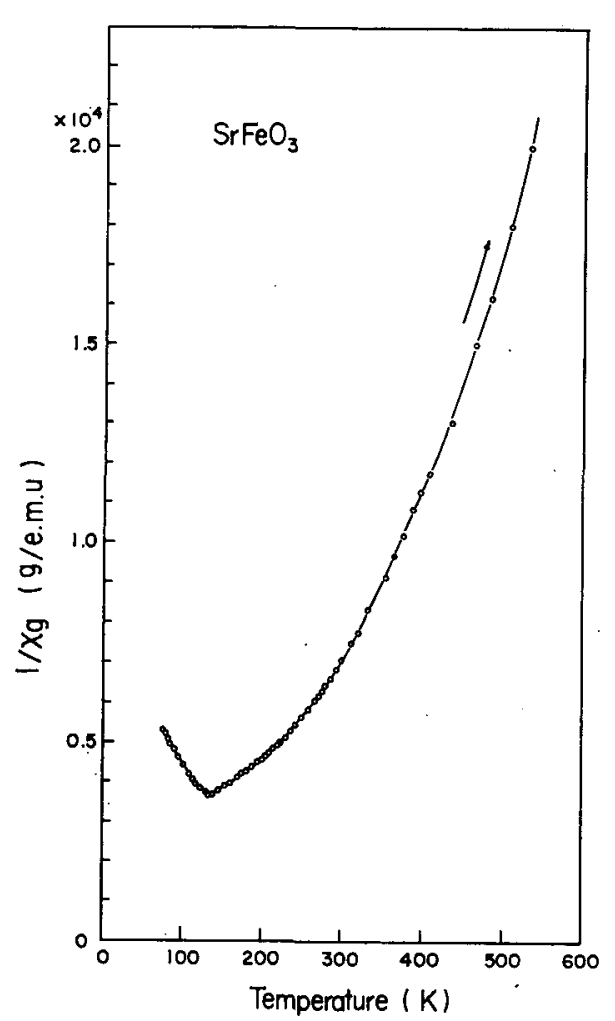

図 $10 \quad \mathrm{SrFeO}_{3}$ の逆帯磁率一温度曲線

らによって得られているが，われわれのデータす彼らと そうちがわない，むし $\mathrm{SrFeO}_{3}$ がイオン結晶であるなら， $\mathrm{Fe}$ は $\mathrm{Fe}^{4+}$ の状態にあることになり，それは $\mathrm{d}^{4}$ の電子 構造であるか⿰ら $\mathrm{Mn}^{3+}$ と似て Jahn-Teller 効果を示すは ずである、しかし $\mathrm{SrFeO}_{3}$ は立方晶ぺロブスカイトであ って, Jahn-Teller 効果は認められない。 また電気伝導 度はかなり大きい值をむっていることは以前の测定 ${ }^{2)}$ ら知られている。これらのととは, $\mathrm{SrFeO}_{3}$ がイオン絃 晶とは考えにくく，むしろバンド模型で記述される心゙き 物質であることを物語っている。

さらに與味あるのは磁気構造である. 図11に波窒温㡲: での中性子回折の結果を示す. 立方晶ペロブスカイトの 核散乱線以外に，幾つかの基本格子では整数の指数付け ができない磁欲散乱線が出現する. とれを解析すると磁 気構造はスクリューで，その伝播ベクトルは[111] 方向 にあり，その大きさは $0.112 a^{*}\left(a^{*}=2 \pi / a\right)$ であることが わかる. これからスピンが平行に揃った層のスピンと次

* $\mathrm{Sr}_{2} \mathrm{Fe}_{2} \mathrm{O}_{5}$ の中性子回折データを解析する過程で計算強度 と夷測強度が十分よい一教を示さないことが認められた。 これに関して本年 9 月京都の国際結晶学会議出席のため来 日したソ連の Solov'ev (Karpov Inst.) とよれ代, 従来発 表されている $\mathrm{Sr}$ の散乱振幅 $b_{\mathrm{Sr}}=-0.58 \times 10^{-12} \mathrm{~cm}$ 岋よ い值ではなく， $b_{\mathrm{St}}=-0.706 \times 10^{-12} \mathrm{~cm}$ が正しいという， この改良された值を用いると, 計算強度と实湘強度の一致 山確か改善される。 


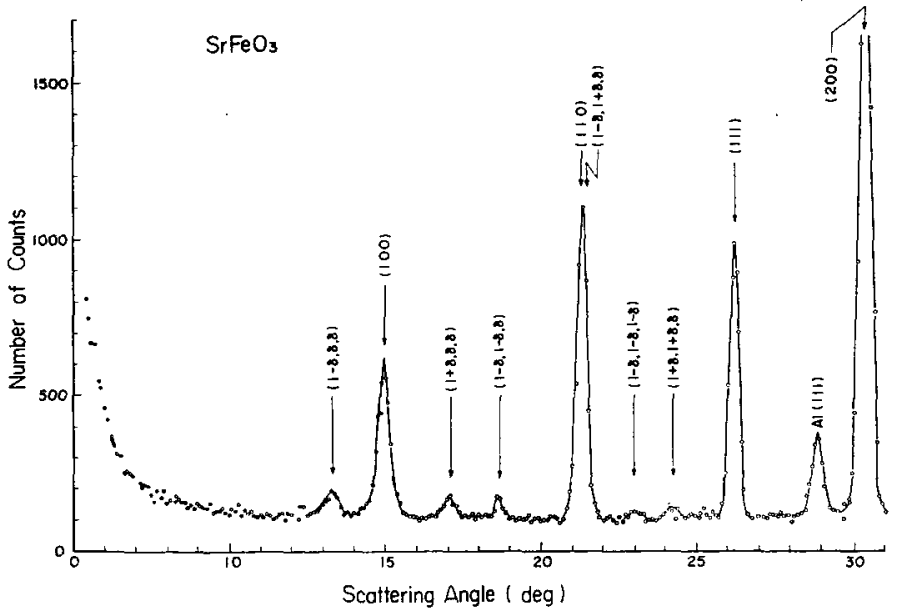

图 $11 \mathrm{Sr}^{\mathrm{FeO}} 3$ の中性子回折像 (液空温度)

2 ，相 $3 ，$ があり，相 3 はさらに $a, b, c の$ 3 種類比細分される. また低温相として相 4 がある. 各相の作製条件，結晶型単位胞 の大きさなどは表 1 に示した，相 $3 b$ と $3 c$ は結晶型の差は見当らないが，磁性に明確 な差があるので区別した。

相 $1\left(\mathrm{Sr}_{2} \mathrm{Co}_{2} \mathrm{O}_{5}\right.$ 相) 空気中 $950^{\circ} \mathrm{C}$ 以上 の温度で熱処理後急冷によって得られるが， X線回折像はブラウンミレライト型に近い 構造であるととを示す．化学分析の結果む 化学式 $\mathrm{Sr}_{2} \mathrm{Co}_{2} \mathrm{O}_{5}$ 江近い. L加し十分注意

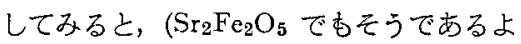
うに） $h+k+l=2 n+1$ ( $n$ は整数) の線か 観測されないので, 空間群はP cmnより対

の層のスピンの間のなす角が $45^{\circ}$ であることになる.因 みにこの角度は $\mathrm{G}$ 型反強磁性構造では $180^{\circ}$ である，Fe の原子磁気モーメントは液空温度で約 $2.7 \mu_{\mathrm{B}}, \mathrm{T} \rightarrow 0$ て $3.5 \mu_{\mathrm{B}}$ と思われる.

一体単鈍ペロブスカイト構造で $\mathrm{Fe}$ 原子の第 1 , 第 2, 第 3 隣接原子間の相互作用を考える籍囲では安定な磁気 構造は A， C, G，Fの 4 種に限られることがいえる. この うちAおよびGは図2 亿示したものであり，C型という のは $c$ 弾方向に並んだ列の Fe 原子の磁気モーメントが 全部揃っているが，相隣る列同志は反平行であるような 反強磁性構造であり，またF型は強磁性である．さて現 実には $\mathrm{SrFeO}_{3}$ の磁気構造住上述のようにスクリューで あるから，この4つの型のいずれでもない.ということ は第 4 隣接原子またはそれ以上遠い距離の原子同志の交 換相互作用が無視でき始ととを示している.

V $\operatorname{SrCoO}_{x}(2.5<x<3)$ 系の状態図 ${ }^{9)},{ }^{14)}, 15$ )

$\mathrm{SrCoO}_{x}$ には図 12 に示すように高温相として相 1 , 相

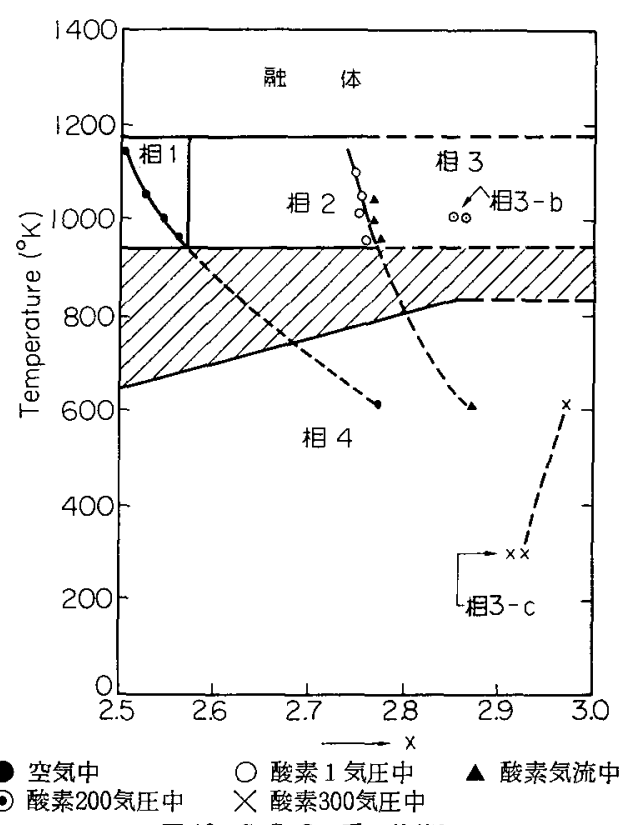

図 $12 \mathrm{SrCoO}_{x}$ 系の状態図

表 $1 \mathrm{SrCoO}_{x}$ 系の種々の相の結晶学的データ*

\begin{tabular}{|c|c|c|c|c|c|}
\hline 作製条件 & 空 気 中 & ${ }_{(1 \text { 酸素圧) }}^{\text {中 }}$ & ${ }_{\text {(気 㳢中) }}^{\text {荎 }}$ & 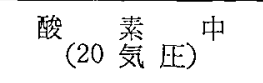 & 酸 \\
\hline $\begin{array}{l}950^{\circ} \mathrm{C} \\
\text { 以上 }\end{array}$ & $\begin{array}{c}\text { 相 }-1 \\
\text { (ブラウンシ斜方晶 } \\
a=5.57_{2} \AA \\
b=15.7_{3} \AA \\
c=5.46_{8} \AA \\
V=59.9_{0} \AA^{3}\end{array}$ & $\begin{array}{l}\text { 相 }-2 \\
2 \text { 柏 }\end{array}$ & $\begin{array}{c}\text { 相 }-3 \mathrm{a} \\
\text { 正方晶 } \\
\text { (ペロブスカイト型) } \\
a=3.83_{8} \AA \\
' c=3.85_{2} \AA \\
V=56.7_{4} \AA^{3}\end{array}$ & $\begin{array}{c}\text { 相 - } 3 \mathrm{~b} \\
\text { 立方鼠 } \\
(\text { ペロブスカイト型) } \\
a=3.84_{0} \AA \\
V=56.6_{2} \AA^{3}\end{array}$ & $\begin{array}{c}\text { 相 }-3 \mathrm{c} * * \\
\text { 立方晶 } \\
\text { (ペロブスカイ型) } \\
a=3.83_{9} \AA \\
V=56.5_{8} \AA^{3}\end{array}$ \\
\hline${ }^{850^{\circ} \mathrm{C}}$ & $\begin{array}{c}\text { 相 }-4 \\
\text { 六方 鼠 } \\
\left(\mathrm{BaNi} \mathrm{O}_{3} \text { 型 }\right)\end{array}$ & $\begin{array}{l}a=5.47 \sim \\
c=4.2 \sim\end{array}$ & $\AA$ & & \\
\hline
\end{tabular}

* $V$ は $\mathrm{SrCoO}_{x}$ の化学単位胞の体積

** $300^{\circ} \mathrm{C}$ で作製 


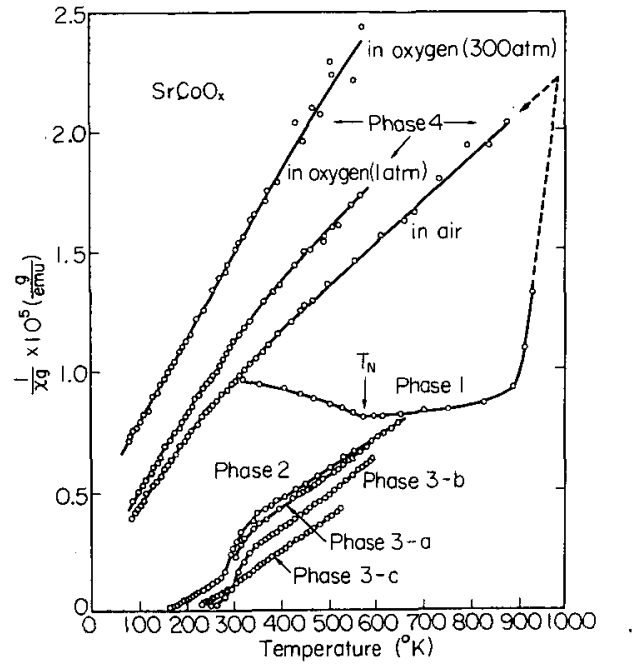

図 $13 \mathrm{SrCoO}$ 系の逆帯磁率一温度曲線

称性のよい $\mathrm{Icmm}$ である可能性むある.

磁性については図 13 亿逆带磁率一温度曲線で示す*よ うに $T_{\mathrm{N}}=575^{\circ} \mathrm{K}$ の反強磁性であり，常磁性キューリー 温度 $\theta_{p}=-280^{\circ} \mathrm{K}$, 有効ボーア磁子数 $\mu_{\mathrm{eff}}=3.60 \mu_{\mathrm{B}}$ (ス ピンに换算すると $S=2.74 / 2)$ であり, $\mathrm{Co}^{3+}\left(\mathrm{d}^{6}\right)$ の high spin state $S=4 / 2$, および low spin state $S=0$ と比較す

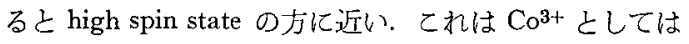
珍しい例である。

中性子回折像は図14に示すように $\mathrm{Sr}_{2} \mathrm{Fe}_{2} \mathrm{O}_{5}$ に似て おり，液窒温度で $(120)+(021)$ の磁気散乱がある. 磁 気構造は $\mathrm{G}$ 型であるが，スピンの向きについては(120) し (021) を分離する実験を行なっていないのでわからな

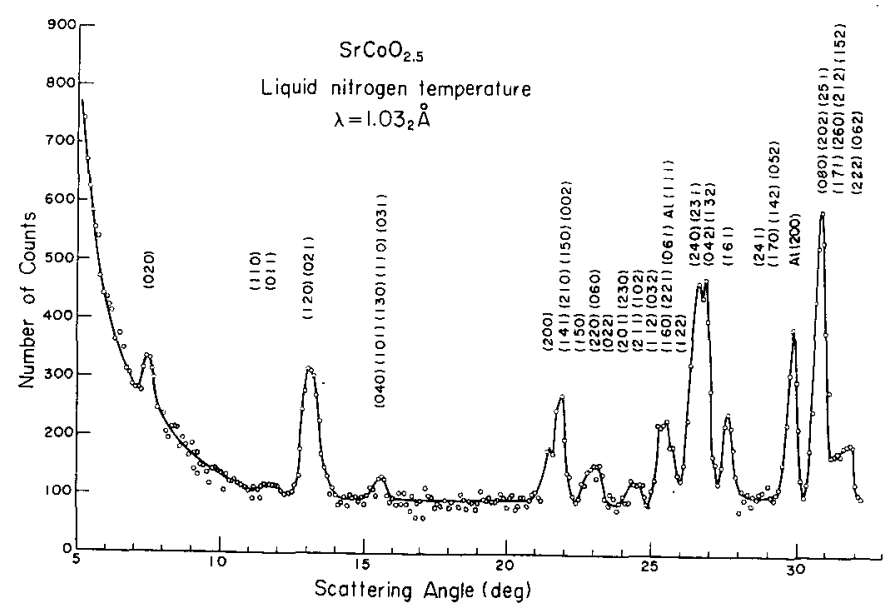

図 $14 \mathrm{Sr}_{2} \mathrm{Co}_{2} \mathrm{O}_{5}$ の中性子回折像 (液窒温度 $\lambda=1.03_{2} \AA$ )

相 $3950^{\circ} \mathrm{C}$ 以上，酸素の供給を十分にして作製後急 冷して得られるが，酸菜圧により $a, b, c$ に分類される (表 1 参照). 高温相であるとする根拠は相 1 同様約 $900^{\circ} \mathrm{C}$ で急激に低温相へ移行するからである.それらの 逆鱼磁率一温度曲線は図13に示す通りであり，両相 $a, b$ はキューリー・ワイス則に従わないが， $3 c$ 相は徒う。こ れらは強磁性であり，磁化一温度曲線は図 15 に示すよう

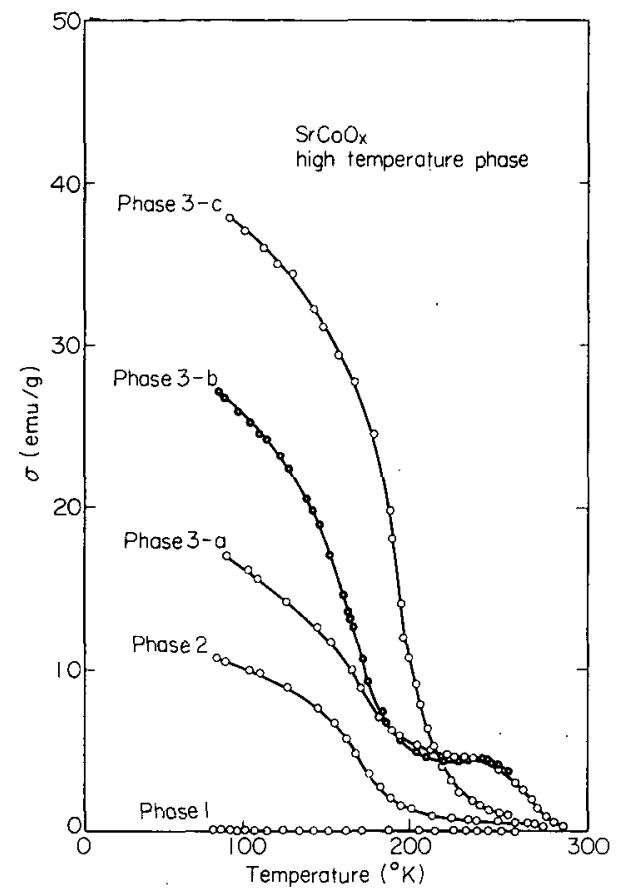

図 $15 \mathrm{SrCoO}_{x}$ 系の磁化・温度曲線

に $a, b$ 雨相については $200^{\circ} \mathrm{K}$ 付近にくび れがある.しかしこのくびれに関して面白 いことは図16に示すように，强い磁場をか けるとくびれは消失して磁化一温度曲線は 滑らかになることである.したがって低磁 場でくびれを生ずることは，乙の温度付近 で単に異方性が大きくなったと考えられな いととすないが，さらにをれ以上本質的な 間題を含んでいる可能性もあるう. たとえ ばメタ磁性またはスクリュー磁気構造を考 えなければならないか子知れない。これは 今後の問題である. $3 c$ 相 $(x=2.95)$ は低磁 場でもくびれはないし，前記のようにキュ ーリー温度以上でキューリー・ワイス則に 從うから，単純な强磁性であるう。しかし

い. $\mathrm{Co}^{3+}$ イオンの磁気モーメントの大きさは液窒温度 で $3.3 \pm 0.5 \mu_{\mathrm{B}}$ であった. 磁気散乱線の強度は带磁率デ 一タで知られた $T_{\mathrm{N}}$ の温度で消える.

相 2 相 1 と相 3 との 2 相である.
図17からわかるように, $\mathrm{SrCoO}_{x}$ の磁気モーメントはCo を $\mathrm{Co}^{4+}\left(\mathrm{d}^{5}\right)$ であるとみるときむしる low spin state に

* $850^{\circ} \mathrm{K}$ 以下のデータのみに意味がある。それ以上では試 料社変㷫し, 低温相飞移行する。 


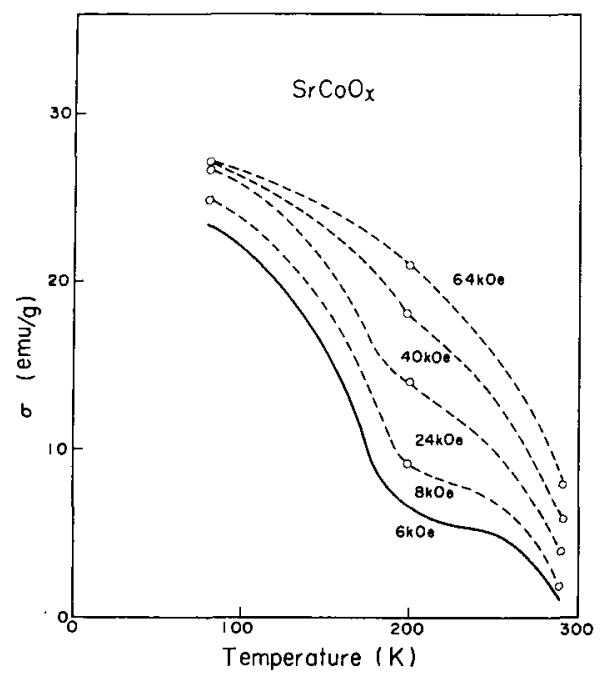

図 $16 \quad \mathrm{SrCoO}_{x}(3 b$ 相， $x=2.87)$ の強磁場に打ける磁 化温度曲線

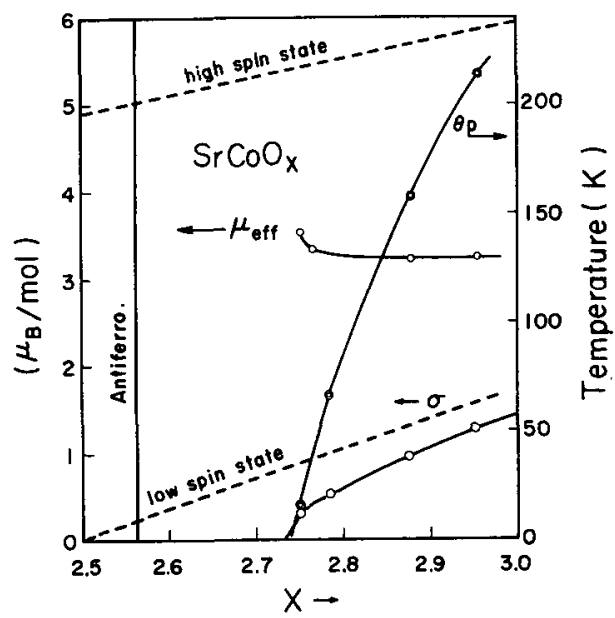

図 $17 \mathrm{SrCoO}_{x}$ 系の磁化 $(\sigma)$, 有効ボーア磁子数 $\left(\mu_{\mathrm{eff}}\right)$ 常磁性キューリー温度 $\left(\theta_{p}\right)$

high spin state, low spin state を表わす点線は

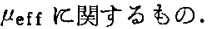

近い值である $(x=0.95,3 c$ の試料に拊いて湤窒温度で $1.14 \mu_{\mathrm{B}} ; \mathrm{Co}^{4+} の$ low spin stateならば $\left.1 \mu_{\mathrm{B}}\right)$. 実際には $\mathrm{SrFeO}_{3}$ 同様イオン結晶上みてはいけない.

相 4 以上はすべて高温相であるが，表 1 および図 12 に示すように相 4 として低温相があり，I（3）項で述べ たように $\mathrm{BaNiO}_{3}$ 型の棈造である。（その逆帯磁率一温度 曲線は図13に示されている通り，酸素圧によって異なる けれどあ，いずれむ小さな带磁率でしかなく，低温でも 液窒温度までの測定では反强磁性にならない。キューリ 一・ワイス則も成立っていない。

以上述べてきたととでだいたい想像できるように酸素 量の少ない $\mathrm{Sr}_{2} \mathrm{Co}_{2} \mathrm{O}_{5}$ はイオン結晶性が強いが，酸素量 が多い ( $x$ が 3 に近い) 試料はイオン結晶とは腾えにく
い.このととは正に電気抵抗の測定によって裏整きされ る. 電気抵抗の測定は次のようにして行なった。すすなわ ち試料を 40 ton プレスで成型し，約 $700^{\circ} \mathrm{C}$ で烧結して 一応の硬さに思的後，それぞれの試料について必要な 熱処理を施した。試料の大きさ你 $2 \times 10 \times 50 \mathrm{~mm}^{3}$ また は $3 \times 3 \times 20 \mathrm{~mm}^{3}$ である.このような試料の霘極として 銀を蒸着し四端子法で测定した。

$\mathrm{Sr}_{2} \mathrm{Co}_{2} \mathrm{O}_{5}$ (相 1) は低温で絶衏体であり，電気抵抗か

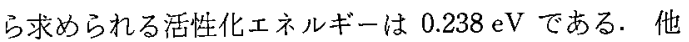
の相はいずれす抵抗は酸化物としてかなり小さい（図 18). 抵抗の絶対值は試料により異なり，特に焼結条件に 強く影響を受ける。低酸素圧の等囲気中で焼結する試料 についてはなかなか結晶は密に烧結しにくい，ての点で

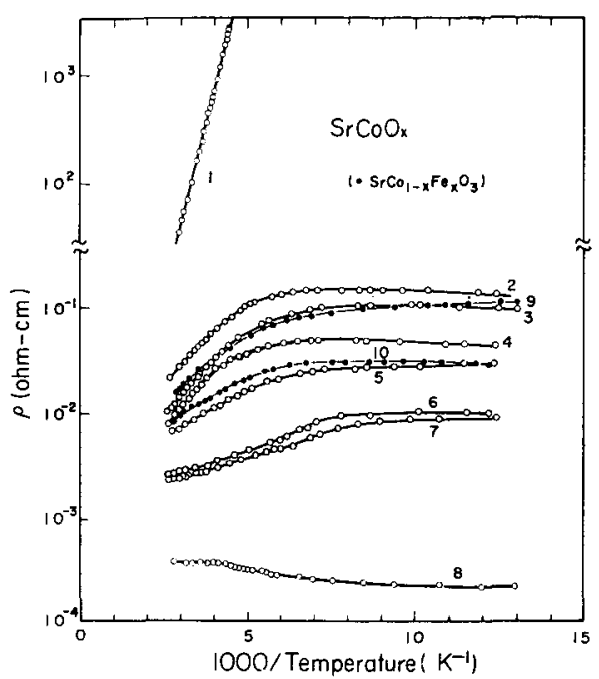

図 $18 \mathrm{SrCoO}_{x}$ 系の電気抵抗 $(\rho-1 / T$ 曲線 $)$

曲線 1: 相1 2: 相 4 (空気中熱処理)

3: 相 4 (酸素気済中熱処理 4: (300気圧酸素䒬囲気)

5: 相 3-c 6: 相 3-a $\quad 7$ : 相 $2 \quad 8$ : 相 3-b

黑丸は $\mathrm{Sr}-\mathrm{Co}_{1-x} \mathrm{FeO}_{3}$ 系の試料 曲線 $9: x=0.8 \quad 10: x=0.5$

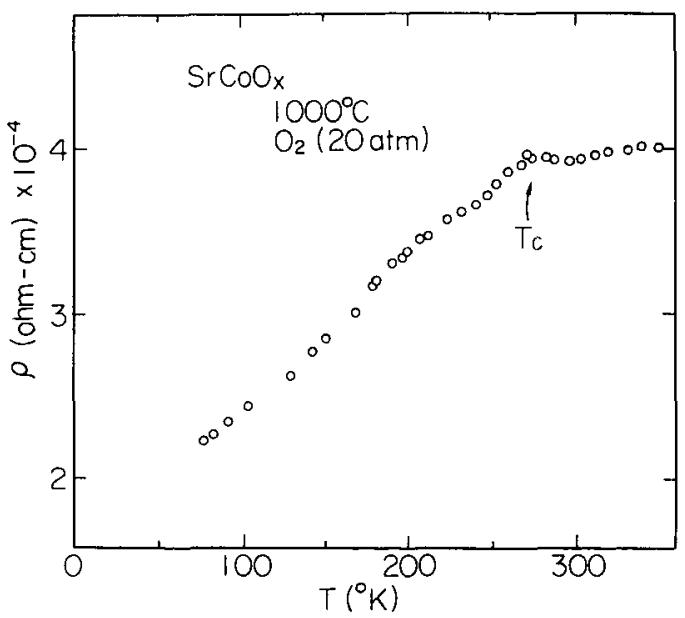

図 19 相 3-b $(x=2.85)$ の電気抵抗一温度 $(\rho-T)$ 曲線 
$1000^{\circ} \mathrm{C} ， 20$ 気圧で熱処理した武料（相 3-b）が最屯密に 陞結されていると考えられ，金属的電気抵抗を示す．特 にての曲線 8 (相 3-b) の武料についてさらに $p-T$ 曲線 で示せば図19のようになる．図に明らかなようにキュー リー点 (図15参照)でかなり鋭い異常が認められる.

これらのデータから想像されることは電気伝導度のよ い試料，特に $x$ が 3 亿近い試料は狭いバンド構造をもつ 物質と考元られる. Goodenough ${ }^{16)}$ は $\mathrm{La}_{1-x} \mathrm{Sr}_{x} \mathrm{CoO}_{3}$
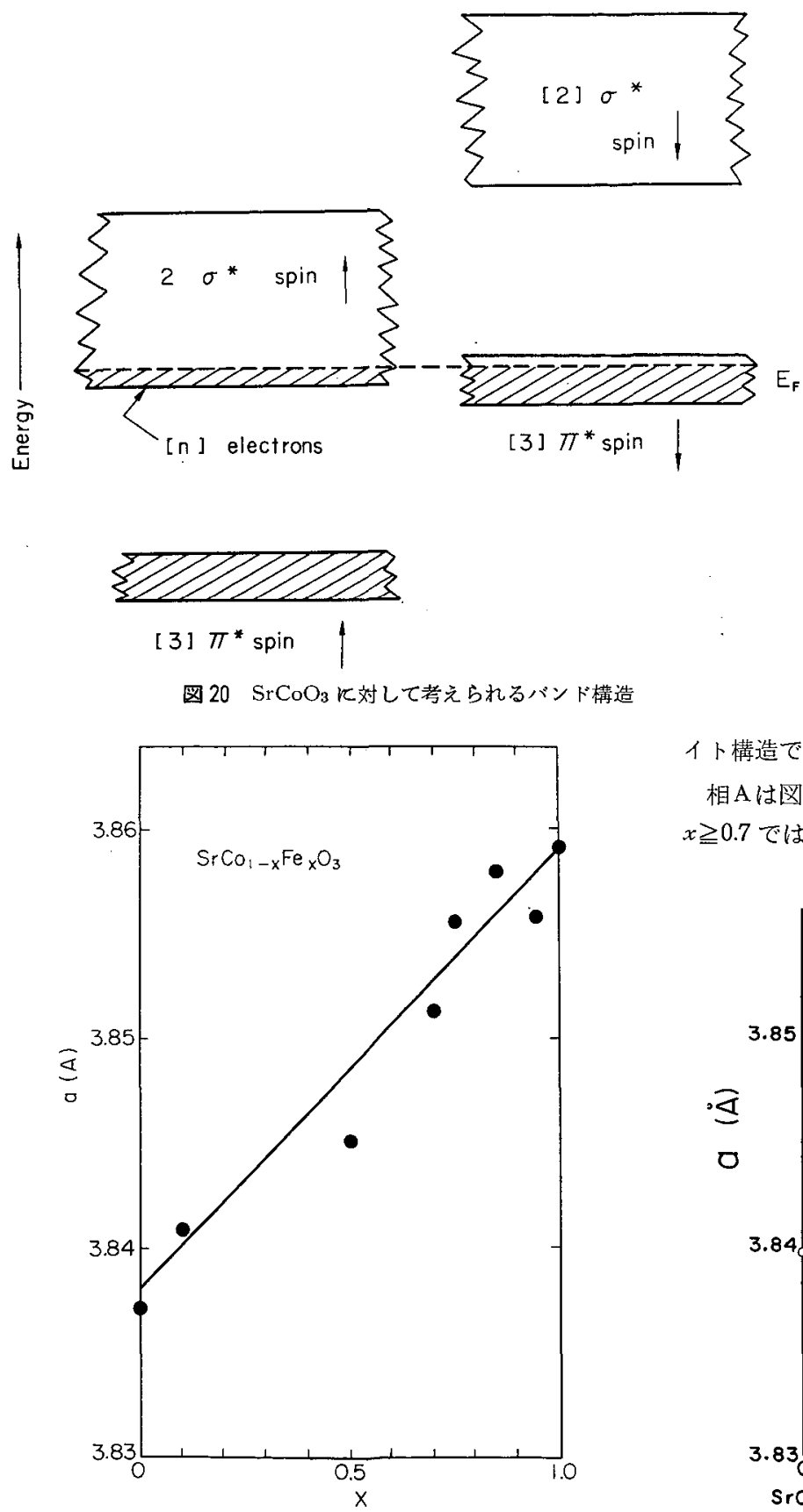

图 $21 \mathrm{SrCo}_{1-x} \mathrm{Fe}_{2} \mathrm{O}_{3}$ 系相 $\mathrm{A}$ の平均の格子常数 $(x>0.5)$ の磁性について図20のようなバンドを考える. 図で $\sigma^{*}$ は $\sigma$ 反結合性バンド $\left(e_{g}\right.$ 対称性をむつ)， $\pi^{*}$ は

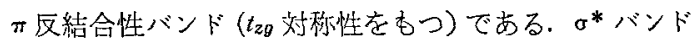
が拡がっていると上，扣よび結晶場が大きいため intraatomic exchange interaction (原子内交換相互作用) が結 晶場に比して相対的に小さくなったととなどの理由から，

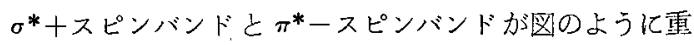
なり，部分的に low spin state になる. この考えがむし 正しければ我々の物質 $\mathrm{SrCoO}_{x}$ にあ同様に 当てはまるものであるう。

$$
\text { VII } \mathrm{SrCo}_{1-x} \mathrm{Fe}_{x} \mathrm{O}_{3}{ }^{15)}
$$

$\mathrm{SrCo}_{1-x} \mathrm{Fe}_{x} \mathrm{O}_{3}$ の固溶体系において我々 の作った䳝料は必ずし屯酸素量は $\mathrm{O}_{3}$ では ないが，便宜的にその上うに書く，試料の 作製法によって次の 2 種を区別する.

a) 相 $\mathrm{A}$

$1000^{\circ} \mathrm{C}$ ，酸素気流中での熱処理で得られ た試料である. ての相は全域でペロブスカ イト摮造であるが，Co の多い組成で少し 正方晶に霆んでいる. 平均の格子常数を図 21 示す.

b) 相 B

$1000^{\circ} \mathrm{C}$ 以上の高温で熱処理後，急冷し た高温相のものを約 $300^{\circ} \mathrm{C}, 300$ 気圧の酸素 雾囲気中での熱好理で得られた相である. この相は全域にわたって立方晶ペロブスカ イト構造である. 格子常数を図22亿示す.

相Aは図23に示すように磁化一温度曲線からみると， $x \geqq 0.7$ では強磁性を示さない，とれに反して相 B は図 24

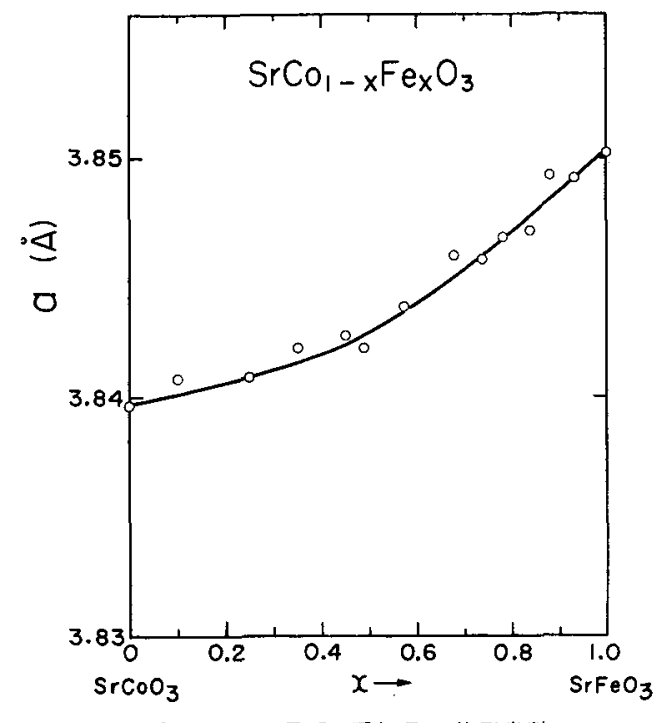

図 $22 \mathrm{SrCO}_{1-x} \mathrm{FeO}_{3}$ 系相 $\mathrm{B}$ の格子常数

「粉体および粉末治金」第 19 巻第 8 号 


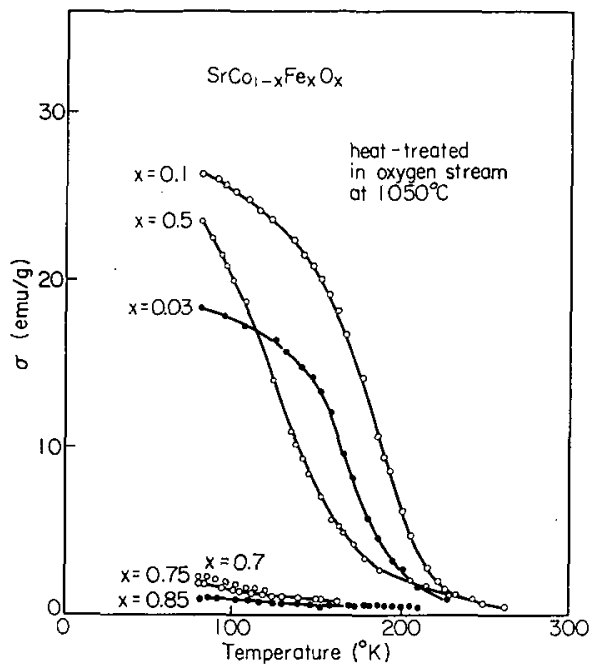

图 $23 \mathrm{SrCO}_{1-x} \mathrm{Fe}_{x} \mathrm{O}_{3}$ 系相 $\mathrm{A}$ の磁化一温度曲線

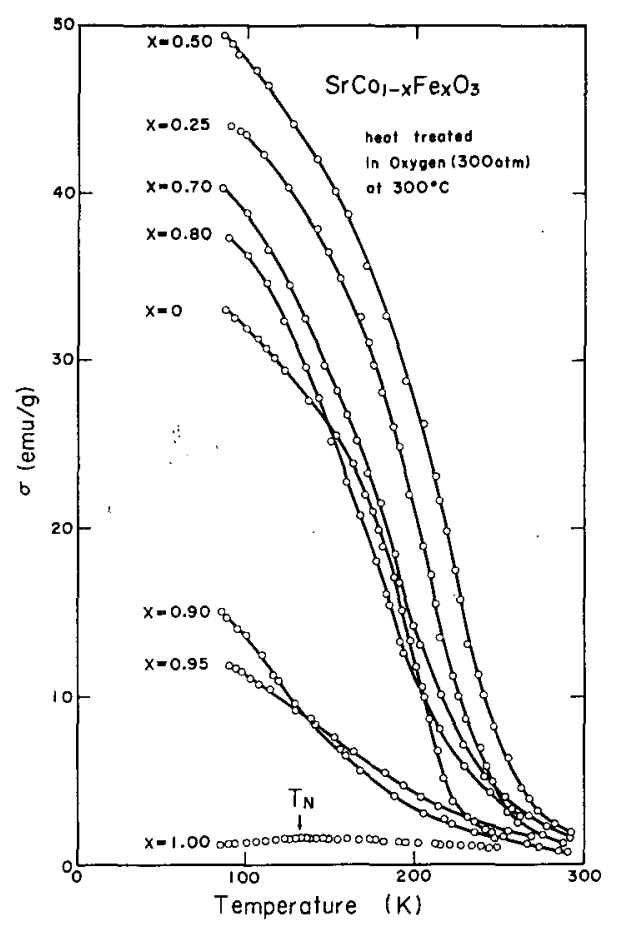

図 $24 \mathrm{SrCO}_{1-x} \mathrm{Fe}_{x} \mathrm{C}_{3}$ 系相 $\mathrm{B}$ の磁化一温度曲線

に示すように磁化は増大し，また強磁性の領域㫗拡がり， $x=0.95$ であ強磁性である. この相 Bについて $\theta_{p}, \mu_{\mathrm{eff}}$ お上び液窒温度での磁化の大きさ $\sigma$ を示す. $x=1.0$ $\left(\mathrm{SrFeO}_{3}\right)$ ではキューリーワイス則が成立っていないの で， $380^{\circ} \mathrm{K}$ 付近の逆带磁率一温度曲線の傾斜から $\theta_{p}$ と $\mu_{\text {eff }}$ 求めた。この图で特長的なととは（1） $x=0.5$ で $\sigma$ が最大となるここ.（2）反強磁性である $\mathrm{SrFeO}_{3}$ を含 めて $\theta_{p}$ が全系を通じて正であることである.なお電気 捪抗一温度曲線は 2 つ代表的試料 $(x=0.8$ と $x=0.5)$ について図18に黒丸で示した.

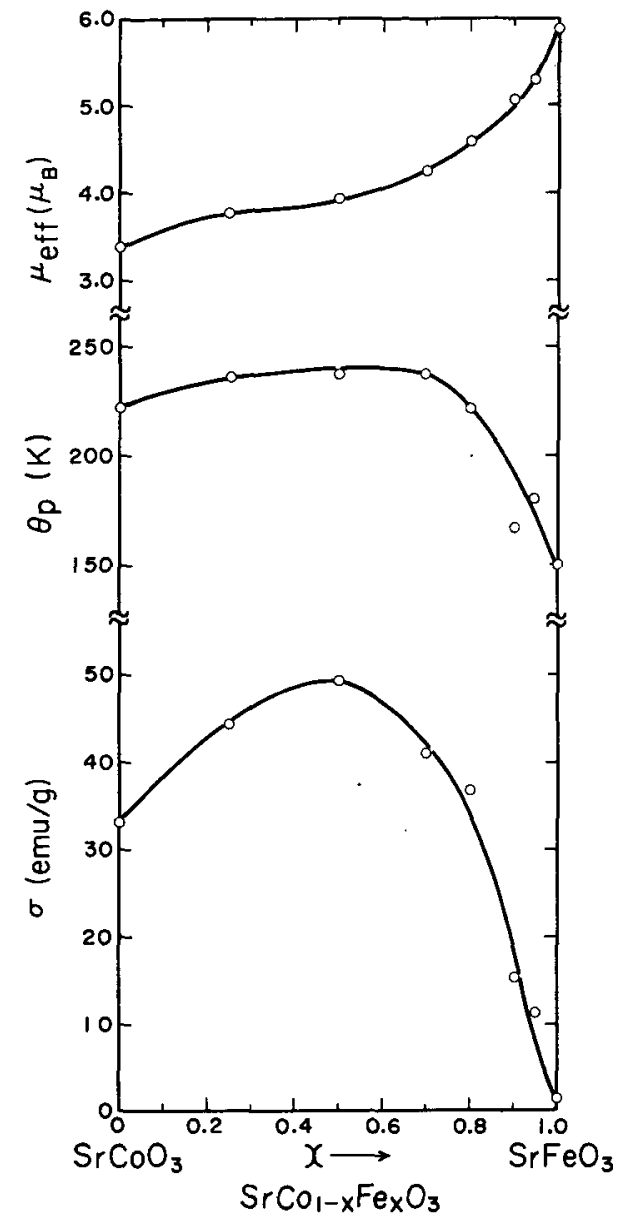

図 $25 \mathrm{SrCo}_{1-x} \mathrm{Fe}_{x} \mathrm{O}_{3}$ 系相 $\mathrm{B} \rho \theta_{\mathrm{p}}, \mu_{\mathrm{eff}} \sigma$ (液窒温度)

$$
\text { VIII ¿ め }
$$

以上述べたように酸素量の多いペロブスカイト型棈造 のフェライト，コバルタイトは伝尊性がよくバンド強磁 性乃至反強磁性と考えられる。市ず $\mathrm{SrFeO}_{3}$ は最む早く このことが注目された物質であるが，その結晶構造はイ オン結晶で予想されるような Jahn-Teller 歪みをむたず, また磁気構造がスクりューであるととから交換相互作用 はかなり長距踓性のあのであるととが知られる。メスバ ウァー効果の結果でも isomer shift はFet イオンとして よりあかなり正の側にシフトして扣り， $3 d$ 電子と $2 p$ 電 子の部分的共有結合のために $3 d$ 電子濃度加堌加し， $4 s$ 電子の電荷を㵂蔽して核位置の $4 s$ 電子溇度を減じてい ると思われる：またスクリュー構造における $0^{\circ} \mathrm{K} に$ 外 插した $\mathrm{Fe}^{4+}$ の磁気モーメント $3.5 \mu_{\mathrm{B}}$ は high spin state の值 $4 \mu_{\mathrm{B}}$ に近いが, $\mathrm{SrCo}_{1-x} \mathrm{Fe}_{x} \mathrm{O}_{3}$ 系で $x$ が減じて Co が多くなると次第に low spin state の方に近ついていく ことが認められる．とのととはこの系での格子常数の組 成変化とよく刘応がつき, Co の多い組成では格子常数 が小さく，結晶場が大きくなっているために low spin 
state に近つくく考えられる. $\mathrm{SrFeO}_{3}$ の中性子回折から 知られたスクリュー構造でのスピンの回転角が $45^{\circ}$ とい うことは，反溞磁性的相互作用とそれに競合する强磁性 的作用の組合せ効果仁よって生じているのであろう， $\theta_{p}$ が正というととはこのととと矛盾しない。

$\mathrm{SrCoO}_{x}$ 加ら $\mathrm{SrCoO}_{3}$ への接近の場合には $\mathrm{Co}^{4+}$ イ才 ン $\left(3 d^{5}\right)$ に $\mathrm{Co}^{3+}$ イオン $\left(3 d^{6}\right)$ がまざっているので,

$\mathrm{SrCoO}_{3}$ 上り $3 d$ 電子数加多い. 一方 $\mathrm{SrCo}_{1-x} \mathrm{Fe}_{x} \mathrm{O}_{3}$ 系 では $\mathrm{Co}^{4+}$ イオンに $\mathrm{Fe}^{4+}$ イオン $\left(3 d^{4}\right)$ がまざっている ので $\mathrm{SrCoO}_{3}$ より $3 d$ 婯子数が少ない. $\mathrm{SrCoO}_{x}$ では $x$

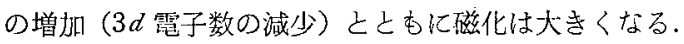
$\mathrm{SrCo}_{1-x} \mathrm{Fe}_{x} \mathrm{O}_{3}$ の場合化む $x$ の增加 ( $3 d$ 電子の減少) 之 と屯に磁化は增加する。 このように磁化は $3 d^{5}$ 近伤で $3 d$ 電子数の隇少上と屯に逨続的に增加する。 乙れは図 200バンドで一スピン $\pi^{*}$ バンドの電子が減少して行く ことに対态している．とのように $\mathrm{Co}^{4+}$ イオンは同じ $3 d^{5}$ である $\mathrm{Fe}^{3+}$ イオンとはまったく買なった振舞を示 すととが明らかとなった。

酸素量の少ない試料 $\mathrm{Ca}_{2} \mathrm{Fe}_{2} \mathrm{O}_{5}, \mathrm{Sr}_{2} \mathrm{Fe}_{2} \mathrm{O}_{5}$ および $\mathrm{Sr}_{2} \mathrm{Co}_{2} \mathrm{O}_{5}$ は電気抵抗が大きく，通常の酸化物同様かな りイオン結晶的な様相を示す. しかし中性子回折の結果 では Fe のモーメントは high spin state の值 $5 \mu_{\mathrm{B}}$ より小 さく, Co のモーメントも同様に $4 \mu_{\mathrm{B}}$ 上り小さい，それ らはいずれも物澌が完全なイオン結晶ではなくて少し共 有結合性をむっているためであると思われる. てのとと は Fe の化合物についてのメスバウァ一效果の実験にお いて，四面体位置の Fe の内部磁場や isomer shift が八 面体位置のそれと少しく異なることにあ現われている。

また $\mathrm{Sr}_{2} \mathrm{Fe}_{2} \mathrm{O}_{5}$ が寄生强磁性をむたないこと，X線回 折像にブラウンミレライト檴造では現われるべき一部の 線が現われないとと，および中性子回折からきめられる スピンの向きから考え合わせて，乙の物質の結晶構造は ブラウンミレライトではなく，それよりあやや高い対称 性の構造であると考えられる. $\mathrm{Sr}_{2} \mathrm{CO}_{2} \mathrm{O}_{5}$ 白同様な事情 である可能性があるが，スピンの向きがまだきめられて
いないので断定できない。

$\mathrm{Sr}_{2} \mathrm{Co}_{2} \mathrm{O}_{5}$ の $\mathrm{Co}$ のモーメントは上述のように high spin state の值 $4 \mu_{\mathrm{B}}$ よりやや低い $\left(3.3 \mu_{\mathrm{B}}\right)$ けれどむ, low spin state の值 $\left(0 \mu_{\mathrm{B}}\right)$ 上りははるかに高い，乙れは 通常 low spin state で存在する $\mathrm{Co}^{3+}$ イオンとしては珍 しいととである. また $T_{\mathrm{N}}=575^{\circ} \mathrm{K}$ というのあこのイオ ンに対して見出されている值としては最高である.

\section{文献}

1) H. L. Yakel: Acta Cryst. 8 (1955) 394.

2) H. Watanabe: J. Phys. Soc. Japan 12 (1957) 515.

3) G. Shirane, D. E, Cox and R. L. Ruby: Phys. Rev. 125 (1962) 1158; T. R. Clevenger, Jr.: J. Amer. Cer. Soc. 46 (1963) 207

4) H. Watanabe and T. Takeda: Proceedings of the Intern. Conf. Ferrites, ed, Y. Hoshino, S. Jida and M. Sugimoto (University of Tokyo Press, 1971) p. 588.

5) 金丸，三村，宮本，小泉，島田，久米，新：本協会昭和 45年 5 月春季大会 (東京) 発表.

6) $180^{\circ}$ 超交換相互作用炕関しては例总は～J. B. Goodenough: Magnetism and the Chemical Bond (Intersci, Publ.N.Y., 1963) または J. Kanamori: J. Phys. Chem. Solids 10 (1959) 87 または P. W. Anderson: Phys. Rev. 115 (1959) 2. 参照.

7) E. F. Bertaut, P. Blum and A. Sagniéres: Acta Cryst. 12 (1959) 149.

8) E. F. Bèrtaut: Magnetism, ed. Suhl and Rado, p. 149, Academic Press, N.Y., 1963.

9) 武田隆䣡：学位論文 (東北大学, 1971).

10) P. K. Gallagher, J. B. MacChesney and D. N. E. Buchanan: J. Chem. Phys. 41 (1964) 2429.

11) T. Takeda, Y. Yamaguchi, H. Watanabe, S. Tomiyoshi and H. Yamamoto: J. Phys. Soc. Japan 26 (1969) 1320.

12) T. Takeda, Y. Yamaguchi and H. Watanabe: J. Phys, Soc. Japan 33(1972) 967.

13) J. B. MacChesney, R. C. Sherwood and J. F. Potter: J. Chem. Phys. 43 (1965) 1907.

14) T. Takeda, Y. Yamaguchi and H. Watanabe: J. Phys. Soc. Japan 33 (1972) 970.

15) T. Takeda and H. Watanabe: J. Phys. Soc. Japan 33 (1972) 973.

16) P. M. Raccah and J. B. Goodenough: J. Appl. Phys. 39 (1968) 1209. 